\title{
Law Enforcement Mining in Indonesia Environmental Law Perspective
}

\author{
Saproni \\ Student at Doctoral Program of Law \\ Universitas Borobudur \\ Jakarta, Indonesia \\ sapronisangadi@yahoo.com
}

\author{
Faisal Santiago \\ Faculty of Law \\ Universitas Borobudur \\ Jakarta, Indonesia \\ faisalsantiago@borobudur.ac.id
}

\begin{abstract}
Mining is one of the main sectors of foreign exchange revenues that have potential nili compared to other sectors, in addition to providing positive impacts in various fields of economic, social-cultural and environmental impacts, but also raises some of the problems that can not be avoided is environmental problems. Environmental Impacts on mining is an aspect that needs to be highly highlighted due to close mining with the opening of mining areas and unfair ecological exploration. Environmental law and mining law are expected to anticipate any attempt to pollute or damage the environment due to mining. Environmental law is more progressive with the birth of Law No. 32 of 2009 on Environmental Protection and Management (UUEPM) because this law regulates the protection and management of the environment and recognizes the strict liability. In the previous Environmental Law No. 4 of 1982 on the Basic Provisions of Environmental Management and Law No. 23 of 1997 on Environmental Management only regulate management without any protection to the environment. Law No. 4 of 2009 on Mining of Minerals and Coal (Mining Law) provides a new understanding of the concept of modern mining law after so far the mining regime for more than 42 years in Indonesia is subject to Law No. 11 of 1967 Basic Provision of Mining. The new Mining Law stresses the spirit of transparency, participation and environmental insight. Mining Law and UUEPM are expected to run synergistically in the aspects of preventive and repressive law enforcement at every stage of mining activity has the biggest exploration and exploitation aspect of the environment because the object is located on land where mining activities always provide environmental effects, pollution and environmental destruction. The Mining Law and UUEPM are the regulations that provide security in mining so that mining is not only beneficial to the Indonesian people but also environmentally friendly and achieves ecological justice and supports the development of Indonesia. Because the mine is a natural resource that takes a long time to be renewed, so it becomes a joint task, especially the role of Environmental Law to be able to maintain its sustainability.
\end{abstract}

\section{Keywords - law enforcement, mining, environmental law}

\section{INTRODUCTION}

The topic of mining in developing countries has been a hot issue from the past until now. In a book entitled Escaping The Resource Curse edited by one of the world's economists Joseph Stiglitz instead shows a huge loss for a State which gives freedom to developed countries to invest heavily in the field. It can not be denied that the income generated from the process and the output is very promising. But who is it for, big companies or just a handful of people in the government who do not care what the effects are after the exploitation does not continue.

The study of Article 33 of the UUD 1945is always buzzing and used as the basis for mining management in Indonesia. Even this becomes an issue that is obsolete and more economic justice than ecological justice. Environmental issues always arise when there has been destruction and or pollution or then there is a victim of a business activity. Environmental law awareness began to emerge when awareness about the environment began to be internationally echoed at the Stockholm Conference 1972 and began to be implemented into Indonesian law ten years later with the birth of Law no. 4 of 1982 and later became Law no. 23 of 1997 which is the Umbrella Act. And the last is Law no. 32 of 2009 on Environmental Protection and Management.

Indonesia's mining history begins with Freepot's first concession rights right with unlimited exploitation and can be extended at any time to make Indonesia already suffer economically and socially losses. This is driven by the President's policy in the New Order era under the pretext of development to make us lulled. The New York Agreement agreed upon after the downfall of President Soekarno and subsequently replaced by President Soeharto opened a vast door for the freedom of exploitation of Indonesia's natural resources. Law No. 1 of 1967 on Foreign Investment, Law no. 5 of 1967 concerning Forestry and then Law No.11 of 1967 seemed to be a crime organized Act.

The effects of these mining activities are not only economic losses but also cause an upsetting social upheaval. Call it increasing escalation of friction between mining companies with the community, the changing pattern of agrarian society into mining communities and the last one that always be the subject of discussion is the damage and contaminated areas around the mine. Although there is an attempt to repair the damage or contamination, but still felt less and did not touch the substantive thing.

Law No.11 of 1967 on the Mining Basic Principles of my visit does not at all mention explicitly the regulation of prevention and restoration of the area around the mine. Only later in PP. 75 of 2001 on the Second Amendment to PP. 32 of 1969 on the Implementation of Law no. 11 Year 1967 little set about it. Among others are regulating the cost of reclamation guarantee and environmental management and monitoring activities (Article 41 paragraph 1e), supervision of the protection of the mining environment including post- 
mining land reclamation and conservation and enhancement of added value (Article 64 paragraph $3 \mathrm{~d}$ and e) with the local government through environmental monitoring and reclamation implementation (article 67), while the more detailed matters are not regulated in the PP.

Law No. 4 of 2009 on Mineral and Coal Mining began to open new horizons about the juridical aspect of mining management from its environmental aspect as well as also mentioned about Indonesia's mining independence. From the environmental aspect of the Act began to accommodate some environmental problems, although in principle the environment is still a lot to be missed especially when we look at the idea of Regulatory Chain proposed by Seerden and Heldeweg.

Of the UUD 1945Article 33 paragraph 3 clearly states that "Earth, water and natural richness contained therein are controlled by the State and used for the greatest prosperity of the people". Simply all that is produced from Indonesia's natural wealth is only for the people of Indonesia. This is the final decision in which we embrace the welfare state. So not for the benefit of individuals, big companies, even the state (Government) of Indonesia itself.

In addition to Article 33 of the 1945 Constitution, in the management of the environment, Article $28 \mathrm{H}$ of the UUD 1945states that "Everyone has the right to live a prosperous and spiritual life, to live and to have a healthy and healthy living environment and to be entitled to health services". According to the writer's opinion that the right to a good and healthy environment is part of human rights in addition to other human rights. Of course this is not only aimed at humans as users of the environment but also the natural rights themselves not to be damaged or polluted by the parties who are not responsible. Furthermore, in Article 5 paragraph 1 of Law no. 23 of 1997 on Environmental Management states that "Everyone has equal rights over a good and healthy environment". Of the several norms mentioned above, it is clear that any type of business that is related to environmental activities and has the potential to change in this case is damaging or polluting must pay attention to the principles and norms listed in the above and related legislation including mining industry activities inside it.

\section{RESEARCH METHODS}

This paper was arranged using normative juridical research type, that is research focused to study the application of positive law principles. Normative juridical is an approach that uses positivist legit conception. This research uses approach of legislation and case approach.

The specification used is descriptive research specification that is a research that aims to provide a concrete description or explanation of the object or problem under study without taking conclusions in general.

In this study it is generally distinguished between data obtained directly from the public and library materials. Obtained directly from the community is called primary data (or baseline data), whereas those obtained from library materials are commonly called secondary data.

The results are presented in the form of descriptions arranged systematically, meaning that the secondary data obtained will be linked with each other tailored to the problems studied, so as a whole is a unified whole in accordance with the needs of research.

\section{PROBLEM FORMULATION}

From the background of the above problems the author takes the following problems:

1. How is environmental monitoring in the mining sector in Indonesia?

2. What is the enforcement of environmental laws that are administrative in Indonesia?

3. How is the enforcement of environmental laws that are criminal in Indonesia?

\section{DISCUSSION}

\section{A. Environmental monitoring in the mining sector in Indonesia}

Law No. 32/2009 on Environmental Protection and Management (UUEPM) came into force on October 3, 2009 replacing Law no. 23 of 1997 on the Management of the Environment (UUPLH). In Chapter XII Article 71 of the UUEPM states that: (1) The Minister, the governor, or the regent / mayor in accordance with his / her authority shall supervise the compliance of the party responsible for the business and / or activity on the provisions stipulated in the laws and regulations in the field of protection and management living environment. (2) The minister, governor, or regent / mayor may delegate his / her authority to supervise the responsible technical officer / agency in the field of environmental protection and management. (3) In conducting supervision, the Minister, governor, or regent / mayor shall appoint an environmental supervisory officer who is a functional official.

In this case it may be explained that government and local officials in accordance with the field of environmental protection and management and have the authority to perform oversight to ensure and ensure that the accountant of the business and or activity has complied with the prevailing laws and regulations. The Government and the Regional Government may also establish environmental monitoring officers.

Article 73 of the UUEPM affirms that: The Minister may supervise the compliance of the party responsible for the business and / or activities whose environmental permit is issued by the local government if the Government considers serious violations in the field of environmental protection and management. This Article gives the government wide authority to exercise oversight of existing environmental permits in the area in case of serious violations. According to

the explanation of a serious violation is a violation is an act of unlawfulness which results in contamination and / or damage to the environment is relatively large and cause unrest in the community. So if in this case environmental violations occur seriously and need more handling, then the Government has the authority to perform certain legal actions so that the pollution and / or destruction done by the party responsible for the business andlor activity is not widespread and can be handled immediately. In article 74 UUEPM also explained about the authority of environmental supervisory officer (PPLH), coordination between PPLH and PPNS as well as prohibition for the responsible of business and / or activity to obstruct PPLH activities. 
Supervision of authorized apparatus includes environmental management, reclamation and post-mining article 141 letter h Law no. 4 of 2009 on Mineral and Coal Mining (Minerba Act). According to Article 141 of the Minerba Law, the Government in this case the Department of Energy and Mineral Resources through the Directorate General of Mineral and Coal Mining may supervise the mining operations in the regions and may delegate authority to the provincial government to conduct supervision on regional administrations.

Especially regarding environmental monitoring in the field of mining is on environmental management, reclamation and post mining. Regarding environmental management related to environmental instruments including Environmental Quality Standard (BML), Criteria of Environmental Damage Standard (KBKL), Environmental Impact Assessment or UKL and UPL as well as environmental permit. Reclamation and post mining related to the recovery and improvement of environmental quality used after mining activity. Government Regulation no. 55 Year 2010 on Coaching and Supervision of Mineral and Coal Mining Business divides supervision in 3 things, namely:

a. General Supervision (Article 13):

b. Supervision over the Implementation of Mining Business Management; (Article 14)

c. Supervision over the Implementation of Mining Activities (Article 16).

In particular, the regulation on supervision over the implementation of mining business activities related to the environment is in Article 16 letter $\mathrm{h}$ of Government Regulation no. 55 of 2010 on the fostering and supervision of the implementation and Management of Mineral and Coal Mining Businesses. Si in further explanation of Article 28 of the PP stated that: Supervision of environmental management, reclamation and post-mining as referred to in Article 16 letter h.

\section{B. Environmental Law Enforcement Administratively}

The enforcement of administrative environmental law aims to avoid unlawful acts or waivers which do not qualify, stop and revert to the original state (before any violation). Administrative law emphasizes action, in contrast to criminal law that emphasizes the legal subjects of polluters or environmentalists. In addition to retribution, it is also a pain for the maker and to satisfy individual and collective victims. Administrative tools can be enforced with the ease of environmental management, especially in the financial sector, such as the reduction of import duty on pollution prevention tools and bank loans for management costs etc. Sanctions

Administration mainly has an instrumental function that is controlling forbidden acts. In addition, administrative sanctions are directed to the protection of interests guarded by the breached provisions. Law no. Law No. 32 Year 2009 on Environmental Protection and Management (UUEPM) states that: The Minister, Governor or Regent / Mayor shall impose administrative sanctions to the party responsible for the business and / or activity if under the supervision found violation of the environmental permit. Administrative sanctions according to Article 76 paragraph 2 of the UUEPM include: a. written warning;

b. government coercion;

c. freezing of environmental permits; or

d. revocation of environmental permits.

So the sanctions are a sequence of imposition of sanctions from a written warning to the revocation of a permit. But in Article 80 paragraph 2 states that the imposition of government coercion may be imposed without a reprimand if a violation made:

a. a very serious threat to humans and the environment;

b. greater and wider impacts if not immediately stopped pollution and / or destruction; and / or;

c. greater damage to the environment if not immediately stopped pollution and / or destruction.

Administrative sanctions according to Article 151 paragraph 2 of Law no. 4 of 2009 Concerning Mineral and Coal Mining (Minerba Law) stipulates administrative sanctions in the form of:

a. Written warning;

b. suspension of some or all of the exploration or production operations; and / or;

c. revocation of IUP, IPR and IUPK.

So basically the imposition of administrative sanctions in the UUEPM and the Minerba Act is the same only in the UUEPM add the aspect of government coercion in the form:

a. temporary suspension of production activities;

b. transfer of production facilities;

c. closure of sewerage channels or emissions;

d. demolition;

e. seizure of potentially infringing goods or devices;

f. suspension of all activities; or

g. other measures aimed at stopping abuses and restoring environmental functions.

\section{Law Enforcement of the Criminal Environment}

According to Law no. 32 Year 2009 on the Protection and Management of the Environment, the purpose of imposing criminal sanctions for the initiator of business and / or activity is madness. So either the person or legal entity that pollutes and / or damages the environment is expected to be deterrent (detterent effect) and not repeat his actions. In the UUEPM also recognize sanctions in the form of imprisonment and fine. There are several matters concerning the application of criminal sanctions in UUEPM related to mining activities, namely:

a. Regarding environmental quality standards. In paragraph 1 of Article 100 UUEPM stipulates that any person violating the water quality standard, emission quality standard or quality standard of imprisonment shall be punished with imprisonment for a maximum of 3 (three) years and a maximum fine of $\mathrm{Rp}$. $3,000,000,000.00$ (three billion rupiahs). But in paragraph 2 of Article 100 it states that the imposition of this offense may be imposed if the administrative sanctions imposed are not obeyed or violations committed more than once.

b. B3 waste. Article 103 states that Any person who produces B3 waste and does not carry out management as referred to in Article 59 shall be punished with 
imprisonment of at least 1 (one) year and a maximum of 3 (three) years and a fine of at least Rp1,000,000,000.00 (one billion rupiah) and a maximum of Rp3,000,000,000.00 (three billion rupiah).

c. Associate with the environmental permit. Article 109 states that any person conducting business and / or activity without an environmental permit referred to in Article 36 paragraph (1) shall be subject to imprisonment of a maximum of 1 (one) year and a maximum of 3 (three) years and a minimum fine Rp1,000,000,000.00 (one billion rupiah) and a maximum of Rp3,000,000,000.00 (three billion rupiah). Article 36 paragraph 1 relates to licensing requirements on a business / activity.

d. Corporate Crime. This is confirmed in Article 115-118 UUEPM.

e. Additional punishment or disciplinary action in Article 119 of the UUEPM in the form of: (appropriation of profits derived from criminal acts, the closure of all or any part of the place of business and / or activity, reparations resulting from a crime, the duty of doing what is neglected without rights; and / company placement under the maximum of 3 (three) years.

Enforcement of Law on Criminal Environment According to Law no. 4 of 2009 on Mineral and Coal Mining. Specific arrangements concerning criminal sanctions for mining activities related to the environment include:

a. Unauthorized mining activities. Article 158 stipulates that any person undertaking a mining business without IUP, IPR or IUPK as referred to in Article 37, Article 40 paragraph (3), Article 48, Article 67 paragraph (1), Article 74 paragraph (1) or paragraph (5) shall be liable to a maximum imprisonment of 10 (ten) years and a maximum fine of $\mathrm{Rp} 10,000,000,000.00$ (ten billion rupiah).

b. Incorrect information or false information. Article 159 states that IUP, IPR or IUPK Holders deliberately submitting reports as referred to in Article 43 paragraph (1), Article 70 letter e, Article 81 paragraph (1), Article 105 paragraph (4), Article 110, or Article 111 paragraph (1) by false or giving false information shall be punished with imprisonment for a maximum of 10 (ten) years and a maximum fine of Rp10,000,000,000.00 (ten billion rupiah).

c. Additional criminal. Article 164 stipulates additional crimes in the form of:

1) appropriation of goods used in committing a crime;

2) appropriation of profits derived from a crime; and / or;

3) obligation to pay expenses incurred due to crime.

\section{CONCLUSIONS}

1. Environmental supervision in the field of mining includes environmental management, reclamation and post mining including environmental management and monitoring in accordance with environmental management documents or environmental clearances that are owned and approved; arrangement, restoration and improvement of land in accordance with its designation; stipulation and disbursement of reclamation guarantee; post-mining management; stipulation and disbursement of post-mining guarantees; and the fulfillment of environmental quality standards in accordance with the provisions of legislation.

2. Law enforcement of the administrative environment in the field of mining in the form of a written warning; suspension of some or all of the exploration or production operations; and / or; revocation of Permission.

3. Enforcement of criminal law in the field of mining in the form of imprisonment and fines for not having permission, providing false information and the application of additional criminal in the form of confiscation of goods used in committing crime; deprivation of profits derived from a criminal offense; and / or the obligation to pay any costs incurred as a result of a crime.

\section{REFERENCES}

[1] Djatmiati, Tatik Sri Prinsip Izin Usaha industri di Indonesia, Disertasi, Program Pascasarjana Universitas Airlangga, 2004.

[2] Hadjon Philipus M, Pengantar Hukum Perizinan, Yuridika, Surabaya, 1994, h. 2 dikutip dari N.M. Spelt \& J.B.J.M. Ten Berge, InleidingVergunningen recht, Utrecht,1994.

[3] Hawkins dalam Koesnadi Hardjosoemantri, Hukum Tata Lingkungan, Gadjah Mada University Press, Yogyakarta, 2005.

[4] Hamzah Andi, Penegakan Hukum Lingkungan, Sinar Grafika, Jakarta, 2005. Peter Mahmud Marzuki, Penelitian Hukum, Prenada Media, Jakarta, 2005

[5] Rangkuti Siti Sundari, Hukum Lingkungan dan Kebijaksanaan Lingkungan Nasional, Airlangga University Press, Cetakan III, 2003, Perangkat Hukum Lingkungan: Dari Ius Constitutum, Sekali Lagi, Ke Ius Constituendum, disampaikan pada Seminar "Good Governance and Good Environmental Governance" yang diselenggarakan oleh Fakultas Hukum Universitas Airlangga tanggal 28 Pebruari 2008 di Surabaya. Saleng Abrar, Hukum Pertambangan, UII Press, Yogyakarta, 2004.

[6] Indonesia, Law No. 4 of 2009 on Mineral and Coal Mining.

[7] _ Law No. 32 of 2009 on the Protection and Management of the Environment.

[8] Government Regulation No. 38 of 2007 on the Division of Authority between the Government and Local Government.

[9] _ Government Regulation No. 55 of 2010 concerning the Coaching and Supervision of Mineral and Coal Mining Business. 